\title{
PREDIKSI KEBANGKRUTAN PT ASURANSI JIWASRAYA DAN PT PRUDENTIAL LIFE INSURANCE : APLIKASI METODE ALTMAN Z-SCORE
}

\author{
Elsie Zandra Amanda ${ }^{1)}$, Apriani Dorkas Rambu Atahau ${ }^{2)}$ \\ ${ }^{122)}$ Program Studi Manajemen, Universitas Kristen Satya Wacana Salatiga \\ Jl. Diponegoro 52-60 Salatiga 50711 \\ 1) zazaamanda11@gmail.com \\ 2)apriani@staff.uksw.edu
}

Diterima: 10 Maret 2020. Disetujui: 06 Mei 2020. Dipublikasikan: Juni 2020

\begin{abstract}
Abstrak
Perusahaan asuransi merupakan lembaga keuangan nonbank yang bergerak di bidang jasa untuk mengatasi risiko yang akan terjadi di masa depan sehingga diharapkan untuk tidak bangkrut. Tujuan penelitian ini untuk membandingkan potensi kebangkrutan PT Asuransi Jiwasraya dan PT Prudential Life Insurance periode 2010 sampai 2017 menggunakan metode altman Z-Score. Kebangkrutan sendiri merupakan suatu kondisi dimana perusahaan tidak mempunyai dana yang cukup untuk menjalankan bisnisnya lagi. Gejala awal dari kebangkrutan yaitu adanya financial distress, yang ditandai dengan ketidakpastian profitabilitas perusahaan di masa yang akan datang. Berdasarkan hasil penelitian PT Asuransi Jiwasraya pada tahun 2010, 2011, 2012, 2015, dan 2016 berada dalam zona abu-abu atau berpotensi untuk bangkrut. Pada tahun 2013, 2014 dan 2017 berada dalam zona bahaya atau perusahaan yang bangkrut. Sedangkan hasil penelitian pada PT Prudential Life Insurance menunjukkan selama periode 2010-2017 termasuk dalam zona abu-abu atau berpotensi untuk bangkrut.
\end{abstract}

Kata kunci: Perusahaan Asuransi, Kebangkrutan, Altman Z-Score

\begin{abstract}
Insurance companies are non-bank financial institutions engaged in services to overcome the risks that will occur in the future so that it is expected not to go bankrupt. The purpose of this study is to compare the potential bankruptcy of PT Asuransi Jiwasraya and PT Prudential Life Insurance for the period 2010 to 2017 using the Altman Z-Score method. Bankruptcy is a condition in which a company does not have enough funds to run its business again. The first symptoms of bankruptcy are financial distress, which is characterized by the uncertainty of the company's profitability in the future. Based on the research results PT Asuransi Jiwasraya in 2010, 2011, 2012, 2015 and 2016 are in the gray zone or have the potential to go bankrupt. In 2013, 2014 and in 2017 it was in danger zones or bankrupt companies. Meanwhile, PT Prudential Life Insurance was in the gray zone during the research period.
\end{abstract}

Keywords: Insurance Company, Bankruptcy, Altman Z-Score

\section{PENDAHULUAN}

Manajemen risiko adalah salah satu cara yang dilakukan untuk menghindari risiko yang terjadi di masa depan, salah satu cara untuk mengurangi risiko yaitu dengan asuransi. Asuransi sendiri merupakan salah satu cara manusia memanajemen risiko atas dirinya sendiri atau barang yang dimilikinya di masa depan. Maka dari itu banyak berbagai tipe asuransi yang ditawarkan oleh perusahaan asuransi. Perusahaan asuransi sendiri adalah lembaga keuangan nonbank yang bergerak dalam bidang jasa yang ditujukan kepada masyarakat untuk mengatasi risiko yang akan terjadi di masa depan (Syilviana \& Rachmawati, 2016). Pendirian usaha memenuhi asumsi going concern yaitu kelangsungan hidup perusahaan tersebut. Namun kelangsungan hidup usaha 
seringkali terancam kebangkrutan yang dapat ditandai oleh kondisi keuangan perusahaan yang dalam keadaan tidak sehat (Rialdy, 2017).

Kebangkrutan adalah kondisi dimana perusahaan tidak lagi mampu menjalani usahanya dikarenakan kekurangan dana. Untuk melihat adanya indikasi kebangkrutan dapat menggunakan rasio keuangan (Toto, 2011). Selain itu, untuk mendeteksi faktor kebangkrutan sejak awal perusahaan dapat melakukan analisis kinerja yang berhubungan dengan kebangkrutan. Risiko kebangkrutan pada perusahaan sebenarnya dapat dilihat dan diukur melalui analisis laporan keuangan (Sinaga et al, 2019).

Permasalahan akan timbul apabila perusahaan asuransi tidak mampu melakukan tugasnya dengan baik. Yang terjadi selanjutnya adalah perusahaan dapat mengalami masalah berupa kebangkrutan hingga penjualan semua aset yang dimilikinya. Saat ini tengah disorot kasus jiwasraya sebagai perusahaan asuransi milik BUMN yang gagal membayar polis JS Saving Plan milik nasabahnya yang mencapai angka triliunan, yang menyebabkan liabilitas perusahaan semakin besar (Prastiwi, 2020). Dari kasus tersebut banyak dugaan yang muncul bahwa ada tindak korupsi di PT Asuransi Jiwasraya ini yang melibatkan beberapa PT lain (Prastiwi, 2020), selain itu juga PT Jiwasraya juga menempatkan sebagian besar sahamnya di perusahaan yang mempunyai kinerja buruk (Ulya, 2020).

Penelitian terdahulu yang terkait tentang prediksi kebangkrutan telah banyak dilakukan baik di perusahaan manufaktur oleh (Peter dan Yoseph, 2011; Adnan dan Arisudhana, 2012; Islamy dan Sumiati, 2015; Kurniawati, 2016; Rialdy, 2017), perbankan oleh (Idawati dan Pratama, 2019). Namun khusus prediksi kebangkrutan yang menggunakan Altman Z-score di bidang asuransi dilakukakan oleh (Syilviana dan Rachmawati, 2016; Nugroho \& Parwito, 2018; Sinaga et al, 2019). Hasil penelitian menunjukkan bahwa terdapat beberapa perusahaan asuransi yang berpotensi mengalami kebangkrutan dan termasuk dalam zona abu-abu atau grey area. Sedangkan penelitian ini merupakan studi kasus pada perusahaan asuransi Jiwasraya, sebuah perusahaan asuransi Badan Usaha Milik Negara (BUMN) yang sudah berdiri sejak 1859 namun sejak tahun 2004 menurut Otoritas Jasa Keuangan (OJK) sudah mengalami masalah keuangan (Prastiwi, 2020).

Masalah yang dihadapi oleh PT Asuransi Jiwasraya bagaikan fenomena puncak gunung es yang artinya masalah yang terlihat di khalayak umum hanyalah masalah kecil padahal masalah yang dimiliki oleh perusahaan besar dan sudah terjadi bertahun-tahun sebelum menyebarnya kasus saat ini, sehingga menarik untuk diteliti lebih lanjut prediksi kebangkrutan PT Asuransi Jiwasraya sebagai early warning system atau sistem peringatan dini.

Maka dari itu penelitian ini dilakukan untuk membandingkan prediksi kebangkrutan antara PT Asuransi Jiwasraya dengan PT Prudential Life Assurance. Selain itu penelitian ini juga memberikan kontribusi agar pihak manajemen Jiwasraya dan Prudential tetap melakukan evaluasi dan meningkatkan kinerja agar di masa mendatang perusahaan terhindar dari potensi kebangkrutan.

\section{TINJAUAN PUSTAKA}

\subsection{Teori Sinyal}

Teori sinyal merupakan teori yang digunakan untuk memberikan sinyal positif (good news) dan sinyal negatif (bad news) tentang laporan keuangan kepada pemakai laporan keuangan. Informasi yang diungkapkan oleh perusahaan memegang peran penting karena hal itu memberikan pengaruh terhadap pengambilan keputusan investasi para investor maupun pihak bisnis yang lain. Apalagi saat perusahaan mempunyai berita buruk (bad news) seperti penurunan kondisi keuangan yang mempunyai sinyal negatif bagi para investor sehingga mempengaruhi pengambilan keputusan investasi. Perusahaan yang efiseien untuk mendapatkan modal akan menyediakan informasi yang relevam dan lebih baik kepada investor dibandingkan dengan perusahaan yang kurang efisien untuk mendapatkan modal (Al-Sartawi, 2016). Laporan 
keuangan digunakan oleh para pemangku kepentingan untuk mengetahui tentang apa yang telah direncanakan oleh manajer perusahaan untuk di masa mendatang (Uyar \& Kilic, 2012).

Spence (1973) memperkenalkan teori sinyal dimana manajemen akan memberi sinyal kepada investor yaiu informasi yang relevan, setelahnya investor akan mengambil sebuah keputusan berdasarkan pada sinyal yang telah diterimanya. Teori sinyal dalam topik financial distress yaitu jika kondisi keuangan yang dimiliki perusahaan baik dan masih stabil, yang nantinya manajer akan menyelenggarakan akuntansi liberal. Sedangkan, jika kondisi keuangan yang dimiliki buruk dan tidak stabil, maka manajer akan menyelenggarakan akuntansi konservatif (Hendrianto, 2012).

\subsection{Kebangkrutan}

Kebangkrutan adalah kondisi dimana perusahaan tidak lagi mampu menjalani usahanya dikarenakan kekurangan dana selain itu perusahaan juga tidak mampu lagi untuk melunasi kewajibannya, sehinga tujuan ekonomi yang ditetapkan perusahaan tidak dapat dicapai (Syilviana \& Rachmawati, 2016). Kebangkrutan yang dianggap sebagai kegagalan dapat didefiniskan bahwa perusahaan kehilangan pendapatannya sehingga tidak mampu menutup biaya yang dikeluarkan oleh perusahaan, yang berarti laba yang didapat oleh perusahaan lebih kecil daripada biaya modal yang dikeluarkan (Rialdy, 2017).

Kebangkrutan juga disebabkan oleh dua faktor, yaitu faktor internal dan faktor eksternal (Hani, 2015). Yang termasuk dalam faktor internal yaitu kesalahan dalam penetapan strategi dan kebijakan serta kurangnya pengendalian. Sedangkan yang termasuk dalam faktor eksternal yaitu tingginya persaingan industri, stabilitas ekonomi dan politik dan kondisi lainnya yang tidak dapat dikendalikan oleh manajemen (Hani, 2015).

Biasanya kebangkrutan dikaitkan dengan beberapa kata diantaranya failure, insolvency dan bankruptcy (Fatmawati, 2016). Menurut Altman (1984), failure terjadi karena tingkat pengembalian atas modal yang diinvestasikan lebih rendah daripada tingkat pengembalian yang berlaku secara umum atas investasi. Sedangkan insolvency terjadi saat perusahaan tidak lagi mampu untuk memenuhi kewajiban jangka pendeknya pada saat jatuh tempo.

Gejala awal dari kebangkrutan yaitu adanya financial distress. Hal ini ditandai dengan adanya ketidakpastian pada profitabilitas perusahaan di masa yang akan datang. Perusahaan dinyatakan bangkrut jika hutang perusahaan lebih besar daripada aktiva yang dimiliki perusahaan, serta perusahaan tidak mampu untuk memenuhi kewajibannya pada kreditor saat jatuh tempo (Hanafi, 2013).

Di dalam bidang asuransi, perusahaan mengalami kerugian jika besar modal dan total penerimaan premi lebih kecil dibandingkan dengan total akumulasi dari klaim yang harus dibayarkan (Fatmawati, 2016). Yang menyebabkan kerugian ini adalah pembayaran jumlah uang klaim yang melebihi batas kemampuan perusahaan tersebut (Fatmawati, 2016).

\subsection{Altman Z-Score}

Burhanuddin (2015) menjelaskan pelopor metode kebangkrutan ialah Beaver (1966), yang dilanjutkan oleh Edward Altman dengan penelitiannya tentang financial distress. Altman (1968) memilih teknik analisis multi diskriminan (MDA) sebagai studi kebangkrutan yang paling tepat, dimana telah dipilih lima variabel yang melakukan pekerjaan terbaik dalam prediksi kebangkrutan perusahaan, yang dikenal dengan Z-Score. Nilai Z-score dihitung menggunakan data keuangan perusahaan yang hasilnya nanti menunjukkan kondisi perusahaan, apakah termasuk dalam keadaan yang sehat atau tidak serta menggambarkan tentang kinerja perusahaan, yang nantinya akan digunakan untuk memprediksi kebangkrutan pada perusahaan. 
Rumus z-score yang terakhir merupakan rumus yang sangat fleksibel karena bisa digunakan untuk berbagai jenis perusahaan, mulai dari yang go public maupun yang tidak go public, selain itu juga cocok untuk digunakan di Negara berkembang seperti Indonesia salah satunya (Rudianto, 2013).

\section{METODE PENELITIAN}

\subsection{Jenis Data}

Jenis data yang digunakan dalam penelitian ini adalah data sekunder berupa laporan keuangan yang didapatkan dari website PT Asuransi Jiwasraya https://www.jiwasraya.co.id dan website PT Prudential Life Assurance https://www.prudential.co.id mulai dari tahun 2010 hingga 2017 yang nantinya akan dianalisis menggunakan metode Altman Z-Score.

\subsection{Alasan Pemilihan Objek}

Peneliti memilih objek PT Asuransi Jiwasraya karena merupakan salah satu perusahaan asuransi jiwa yang awalnya milik Belanda bernama Nederlandsch Indiesche Levensverzekering en Liffrente Maatschappij van 1859 yang pertama kali berada di Indonesia pada tahun 1859, yang terus berganti nama selama beberapa tahun hingga pada tahun 1966 perusahaan asuransi tersebut dikuasai oleh pemerintah Indonesia (BUMN) yang kemudian diintegrasikan ke dalam Perusahaan Negara Asuransi Djiwasraja, dan puncaknya pada tahun 2003 nama perusahaan asuransi tersebut resmi berubah menjadi PT Asuransi Jiwasraya (Persero) hingga sekarang. Yang akhir-akhir ini sering disorot oleh media karena adanya kasus korupsi yang menerpa perusahaan asuransi tersebut (Prastiwi, 2020).

Sedangkan PT Prudential Life Insurance tergabung dalam Prudential Corporation Asia yang merupakan salah satu unit bisnis dari Prudential plc (Inggris) yang salah satunya terdiri dari asuransi jiwa, pertama kali berada di Indonesia pada tahun 1995 dan dilakukan merger antara prudential dengan Bank Bali Indonesia yang namanya menjadi Prudential BancBali Life Insurance. PT Prudential Life Insurance juga merupakan salah satu perusahaan asuransi swasta yang sudah banyak dikenal oleh kalangan masyarakat dan pernah memenangkan penghargaan asuransi jiwa terbaik, kinerja keuangan yang bagus dan masih banyak lagi. Namun sempat beberapa kali PT Prudential Life Inscurance diterpa kabar tidak enak, pada tahun 2004 perusahaan pernah dinyatakan pailit (Leo, 2004) namun disayangkan tak banyak media yang meliput hal ini, serta masih ada beberapa masalah lagi yang menerpa perusahaan ini, salah satunya kabar tentang nasabah yang menggugat asuransi Prudential.

Maka dari itu untuk melihat kinerja dari kedua perusahaan tersebut peneliti melakukan uji Altman Z-score untuk memprediksi kebangkrutan kedua perusahaan tersebut, apakah termasuk dalam perusahaan bangkrut atau tidak.

Metode Altman Z-score merupakan metode yang biasa digunakan untuk memprediksi kebangkrutan suatu perusahaan, yang mengacu pada rasio-rasio keuangan perusahaan. Metode ini pertama kali diperkenalkan oleh Altman (1968) dengan menyusun suatu model yang mempunyai tujuan untuk memprediksi kebangkrutan perusahaan.

Altman Z-score memiliki beberapa versi perhitungan, dikarenakan penelitian ini menggunakan objek perusahaan asuransi yang dianggap sebagai perusahaan non-manufaktur, maka rumus Altman Z-Score yang akan digunakan terdiri atas empat rasio, sebagai berikut: 
Keterangan:

$$
Z=6,56 \times 1+3,26 \times 2+6,72 \times 3+1,05 \times 4
$$

$\mathrm{X}_{1}=$ Modal kerja/total aset

$\mathrm{X}_{2}=$ Saldo laba/total aset

$\mathrm{X}_{3}=$ Pendapatan sebelum pajak/total aset

$\mathrm{X}_{4}=$ Nilai pasar terhadap ekuitas/nilai buku terhadap total liabilitas

Menurut Altman, kriteria kebangkrutan jika:

$Z>2.90$ : termasuk dalam zona aman atau perusahaan yang sehat

$\mathrm{Z}<1.20$ : termasuk dalam zona bahaya atau perusahaan yang bangkrut

Z 1.20-2.90 : termasuk dalam zona abu-abu atau rentan bangkrut

\section{HASIL DAN PEMBAHASAN}

Berdasarkan hasil perhitungan Altman Z-Score yang telah dilakukan oleh peneliti dari tahun 2010 hingga 2017 dapat dijelaskan tentang pengklasifikasian zona. Pada tahun 2010, 2011, 2012, 2015, 2016 PT Asuransi Jiwasraya memiliki nilai Z-score sebesar 1.615, 2.169, 1.595, $1.323,1.548$ yang menunjukkan berada pada zona abu-abu atau rentan bangkrut, hal ini berarti terdapat masalah manajemen maupun struktur pada perusahaan sehingga ada kemungkinan perusahaan untuk bangkrut maupun tidak bangkrut, dan semuanya tergantung pada bagaimana manajemen perusahaan mengelola masalah ini. Sedangkan pada tahun 2013, 2014 dan 2017 PT Asuransi Jiwasraya memiliki nilai Z-Score sebesar 0.998, 1.124, dan 1.041 yang menunjukkan berada pada zona bahaya yang dapat menyebabkan perusahaan memiliki potensi untuk bangkrut.

Tabel 1. Hasil perhitungan altman z-score PT Asuransi Jiwasraya dan PT Prudential Life Insurance

\begin{tabular}{|c|c|c|}
\hline \multirow{2}{*}{ Tahun } & \multicolumn{2}{|c|}{ Nilai Z-Score } \\
\cline { 2 - 3 } & $\begin{array}{c}\text { PT Asuransi } \\
\text { Jiwasraya }\end{array}$ & $\begin{array}{c}\text { PT Prudential Life } \\
\text { Insurance }\end{array}$ \\
\hline 2010 & 1.615 & 2.082 \\
\hline 2011 & 2.169 & 2.342 \\
\hline 2012 & 1.595 & 2.288 \\
\hline 2013 & 0.998 & 1.809 \\
\hline 2014 & 1.124 & 2.110 \\
\hline 2015 & 1.323 & 2.470 \\
\hline 2016 & 1.548 & 2.335 \\
\hline 2017 & 1.041 & 1.327 \\
\hline
\end{tabular}

Hasil penelitian ini sejalan dengan hasil penelitian Sinaga et al (2019), Syilviana \& Rachmawati (2016), Nugroho \& Parwito (2018) yang menghasilkan angka z-score pada kriteria abu-abu.

Dari hasil perhitungan Altman Z-Score pada PT Prudential Life Insurance dapat dilihat bahwa selama periode 2010-2017 nilai Z-Score yang dimiliki termasuk dalam zona abu-abu atau rentan untuk bangkrut karena nilai Z-Score yang dihasilkan berada diantara angka 1.202.90. Maka dari itu peneliti membandingkan nilai z-score yang dimiliki oleh PT Asuransi Jiwasraya dengan PT Prudential Life Insurance, bisa dilihat bahwa hasil akhir yang dimiliki oleh kedua perusahaan hampir sama. Hal itu bisa menggambarkan bahwa kinerja yang dimiliki oleh kedua perusahaan hampir sama buruknya, karena nilai Z-Score yang dimiliki tidak pernah 
termasuk dalam zona aman atau perusahaan yang sehat. Namun PT Prudential Life Assurance memiliki kinerja yang lebih baik daripada PT Asuransi Jiwasraya, karena nilai Z-Score yang dihasilkan selalu berada di zona abu-abu, sedangkan PT Asuransi Jiwasraya memiliki beberapa periode yang termasuk dalam zona bahaya atau perusahaan yang bangkrut.

Selain itu peneliti juga membuat matriks untuk perbandingan antara realita dengan hasil ramalan pada kedua perusahaan. Dari hasil matriks dapat dilihat terdapat beberapa ramalan atau hasil prediksi salah, yang semula hasil prediksinya bangkrut namun dalam realitanya tidak bangkrut. Namun ada juga hasil prediksi yang benar, dimana diprediksikan tidak bangkrut dalam realitanya juga tidak bangkrut. Dimana dapat dilihat pada tabel dibawah ini bahwa pada realitanya PT Asuransi Jiwasraya dan PT Prudential Life Insurance tidak mengalami kebangkrutan, meskipun pada beberapa tahun diprediksi untuk bangkrut, namun tidak bangkrut, serta saat perusahaan termasuk dalam zona abu-abu atau rentan untuk bangkrut manajemen dapat mengelola keuangan dengan baik sehingga perusahaan tidak bangkrut.

Tabel 2. Matriks perbandingan antara PT Asuransi Jiwasraya dengan PT Prudential Life Insurance

\begin{tabular}{|l|l|l|l|}
\hline Perusahaan & Realita & Prediksi & Persen (\%) \\
\hline PTAsuransi Jiwasraya & Tidak bangkrut & Bangkrut & $3 / 8$ \\
\hline $\begin{array}{l}\text { PT Prudential Life } \\
\text { Insurance }\end{array}$ & Tidak bangkrut & Tidak bangkrut & $0 \%$ \\
\hline
\end{tabular}

Angka pada tabel PT Asuransi Jiwasraya didapat dari banyaknya tahun yang diprediksi bangkrut $(2013,2014,2017)$ yang memiliki nilai $\mathrm{z}$-score dibawah kriteria yang kemudian dibandingkan dengan banyaknya periode (2010-2017) sehingga hasilnya menjadi 3/8. Berlaku juga untuk PT Prudential Life Insurance, namun nilai z-score yang dimiliki tidak ada yang kurang dari 1,20 sehingga hasilnya menjadi $0 \%$.

\section{KESIMPULAN}

Berdasarkan hasil perhitungan Altman Z-Score pada PT Asuransi Jiwasraya dan PT Prudential Life Insurance selama periode yang diteliti dapat disimpulkan bahwa kinerja yang dimiliki oleh kedua perusahaan tidak jauh berbeda dengan indikasi berpotensi mengalami financial distress karena nilai Z-score berada pada zona abu-abu. Walaupun demikian, kinerja PT Asuransi Prudential secara konsisten lebih baik mengingat nilai Z-Score yang dimiliki oleh PT Prudential Life Insurance selalu berada di zona abu-abu yaitu antara 1.20-2.90 dengan ratarata nilai z-score 2.013, sedangkan untuk PT Asuransi Jiwasraya terdapat beberapa periode yang termasuk dalam zona bahaya yaitu nilai Z-Score yang kurang dari 1.20 dengan rata-rata nilai Zscore 1.054. Implikasi penelitian ini adalah perlunya dilakukan berbagai upaya, terutama pada bagian $\mathrm{X}_{2}$ yaitu saldo laba terhadap total aset untuk memperbaiki kinerja keuangan kedua perusahaan Asuransi tersebut. Keterbatasan pada penelitian ini yaitu hanya didasarkan pada aspek kuantitatif.

\section{Daftar Pustaka}

Adnan, H., \& Arisudhana, D. (2012). Analisis Kebangkrutan Model Altman Z-Score Dan Springate Pada Perusahaan Industri Property. Jurnal Akuntansi Dan Keuangan, 1(1).

Al-Sartawi, A. (2016). Measuring the Level of Online Financial Disclosure in the Gulf Cooperation Council Countries. Corporate Ownership \& Control Journal, 14(1).

Altman, E. I. (1968). Financial Ratios, Discriminant Analysis And The Prediction Of Corporate Bankruptcy. The Journal of Finance, XXIII. 
Altman, E. I. (1984). A Further Empirical Investigation of the Bankruptcy Cost Question. The Journal of Finance, XXXIX(4), 1067-1089.

Burhanuddin, S. (2015). Aspek Hukum Lembaga Keuangan Syari'ah. Yogyakarta: Graha Ilmu.

Fatmawati, Y. (2016). Analisis Potensi Kebangkrutan Dengan Model Altman Z-Score Pada Perusahaan Asuransi Jiwa Syariah Di Indonesia.

Hanafi, M. M. (2013). Manajemen Keuangan (Edisi Satu). Yogyakarta: BPFE-Yogyakarta.

Hani, S. (2015). Teknik Analisa Laporan Keuangan. Medan: UMSU PRESS.

Hendrianto. (2012). Tingkat Kesulitan Keuangan Perusahaan Dan Konservatisme Akuntansi Di Indonesia.

Idawati, I. A. A., \& Pratama, I. G. S. (2019). Analisis Prediksi Kebangkrutan Pada Sektor Keuangan Bank Yang Terdaftar Di Bei Menggunakan Multiple Discriminant Analysis. 3(1), 45-48.

Islamy, R. D., \& Sumiati. (2015). Indikasi Potensi Kebangkrutan Menggunakan Multiple Discriminant Analysis Model Altman (Z-Score) Pada Perusahaan Textille Dan Garment Yang Terdaftar Di Bursa Efek Indonesia Tahun 2013-2015.

Kurniawati, S. (2016). Analisis Kebangkrutan Dengan Model Altman Z-Score Pada Perusahaan Subsektor Logam \& Sejenisnya Di Bei Periode 2014. Seminar Nasional Cendikiawan 2016.

Leo. (2004, April 23). Prudential Life Assurance Dinyatakan Pailit. In 2004. Retrieved https://www.hukumonline.com

Nugroho, R. E., \& Parwito. (2018). Analyzing The Potential Bankruptcy of Sharia Life Insurance Companies In Indonesia. International Journal of New Technology and Research, 4(10), 54-61.

Peter, \& Yoseph. (2011). Analisis Kebangkrutan Dengan Metode Z-Score Altman, Springate dan Zmijewski Pada PT Indofood Sukses Makmur TBK Periode 2005-2009. Jurnal Ilmiah Akuntansi, 2(4).

Prastiwi, D. (2020, Januari 15). Perjalanan Kasus Jiwasraya Hingga Penetapan Tersangka. Retrieved https://www.liputan6.com

Rialdy, N. (2017). Analisis Prediksi Kebangkrutan Dengan Menggunakan Metode Altman Zscore Paada PT Adhi Karya (Persero) TBK. Jurnal Keuangan Dan Bisnis, 9(1), 79-96.

Rudianto. (2013). Akuntansi Manajemen Informasi untuk Pengambilan Keputusan Strategis. Jakarta: Erlangga.

Sinaga, M. N., Pelleng, F. A. O., \& Mangindaan, J. V. (2019). Analisis Tingkat Kebangkrutan Pada Perusahaan Asuransi Yang Terdaftar Di Bursa Efek Indonesia. Jurnal Administrasi Bisnis, 9(2), 28.

Spence, M. (1973). Job Market Signaling. The Quarterly Journal of Economics, 87(3), 355374.

Syilviana, \& Rachmawati, T. (2016). Analisis kebangkrutan dengan menggunakan model Altman Z-Score pada perusahaan asuransi yang go public di Bursa Efek Indonesia (periode tahun 2010-2013). Jurnal Ekonomi Dan Bisnis, 1(1), 61-74.

Toto, P. (2011). Analisis Laporan Keuangan Teori dan Aplikasi. Jakarta: PPM.

Ulya, F. N. (2020, Januari 09). Simak, Ini Kronologi Lengkap Kasus Jiwasraya Versi BPK. Retrieved https://money.kompas.com

Uyar, A., \& Kilic, M. (2012). Influence of Corporate Attributes on Forward-looking Information Disclosure in Publicly Traded Turkish Corporations. Procedia Social and Behavioral Sciences, 62, 244-252. 
https://www.prudentialcorporation-asia.com

https://www.prudential.co.id

\section{Biodata Penulis}

Elsie Zandra Amanda, lahir di kota Salatiga pada 29 Agustus 2000. Saat ini masih menempuh pendidikan S1 dalam bidang ekonomi di Universitas Kristen Satya Wacana Salatiga. Dan ini merupakan pertama kalinya melakukan penelitian.

Apriani Dorkas Rambu Atahau SE, MCom, PhD., lahir di Salatiga pada 13 April 1974. Memperoleh gelar S1 dari FE UKSW, MCom dari University of New South Wales Australia dan PhD dari Curtin University Australia. Saat ini menjabat sebagai wakil dekan FEB UKSW dan Ketua Dewan Pengawas Dana Pensiun Satya Wacana. Artikel Apriani diterbitkan di berbagai jurnal baik jurnal nasional terakreditasi maupun jurnal internasional bereputasi. Artikelnya yang terbit tahun 2020 pada journal of Cleaner Production yang diterbitkan oleh Elsevier berjudul Rural Microfinance Sustainability: Does Local Wisdom-Driven Governance Work? . Apriani juga melakukan berbagai penelitian bersama tim CEMSED yang didanai oleh Bank Indonesia, Dinas Koperasi, The Asia Foundation dan mendapatkan hibah penelitian dari UKSW dan DIKTI. 